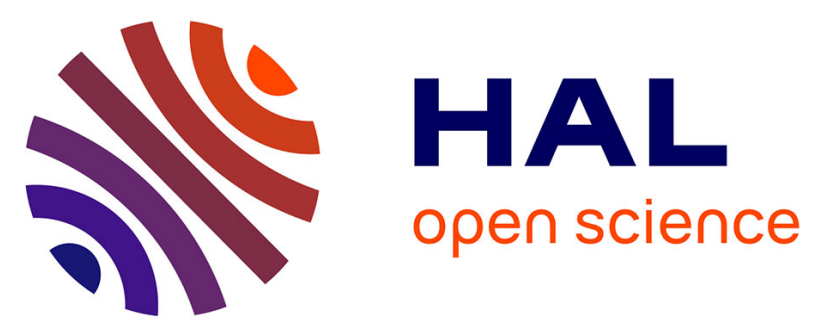

\title{
Plant age and rock phosphate effects on the organic resource quality of herbaceous legume residues and their $\mathrm{N}$ and $\mathrm{P}$ release dynamics
}

\author{
B. Vanlauwe, A. Idrissa, J. Diels, N. Sanginga, R. Merckx
}

\section{- To cite this version:}

B. Vanlauwe, A. Idrissa, J. Diels, N. Sanginga, R. Merckx. Plant age and rock phosphate effects on the organic resource quality of herbaceous legume residues and their $\mathrm{N}$ and $\mathrm{P}$ release dynamics. Agronomy for Sustainable Development, 2008, 28 (3), pp.429-437. hal-00886414

\section{HAL Id: hal-00886414 https://hal.science/hal-00886414}

Submitted on 1 Jan 2008

HAL is a multi-disciplinary open access archive for the deposit and dissemination of scientific research documents, whether they are published or not. The documents may come from teaching and research institutions in France or abroad, or from public or private research centers.
L'archive ouverte pluridisciplinaire $\mathbf{H A L}$, est destinée au dépôt et à la diffusion de documents scientifiques de niveau recherche, publiés ou non, émanant des établissements d'enseignement et de recherche français ou étrangers, des laboratoires publics ou privés. 


\title{
Plant age and rock phosphate effects on the organic resource quality of herbaceous legume residues and their $\mathbf{N}$ and $P$ release dynamics
}

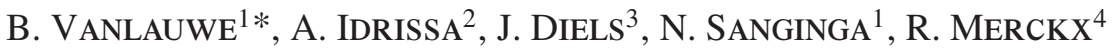 \\ ${ }^{1}$ Tropical Soil Biology and Fertility Institute of the International Centre for Tropical Agriculture, PO Box 30677, Nairobi, Kenya \\ ${ }^{2}$ Ministère des Enseignements Secondaire Supérieure de la Recherche et de la Technology, BP 237, Niamey, Niger Republic \\ ${ }^{3}$ International Institute of Tropical Agriculture, PMB 5320, Ibadan, Nigeria \\ ${ }^{4}$ Department of Land Management, Faculty of Applied Bioscience and Engineering, Kasteelpark Arenberg 20, 3001 Heverlee, Belgium
}

(Accepted 11 March 2008)

\begin{abstract}
Many tropical agro-ecosystems rely on organic resources for nutrient provision. Various factors affect the nutrient release dynamics of organic resources, including application of external nutrients during their growth and their age or physiological stage at the time of harvest. Understanding relationships between organic resource management factors and the resulting nutrient release dynamics is important for optimizing nutrient recovery by crops and minimizing nutrient losses to the environment. Here, Mucuna pruriens and Lablab purpureus legumes were grown on a 'slope' and 'plateau' field, treated or not with rock phosphate, and sampled from 12 to 30 weeks after planting. These plant residues were then incubated in a sandy soil under laboratory conditions and mineral $\mathrm{N}$ and Olsen-extractable $\mathrm{P}$ dynamics were measured for 28 days. Our results showed that plant age had an impact on N, P and polyphenol contents. Application of rock phosphate only altered the $\mathrm{P}$ content of the legumes on the 'plateau' field, which had a lower soil-available $\mathrm{P}$ content. We also observed that mineral $\mathrm{N}$ dynamics of the organic resources varied between $-62 \%$ of the added $\mathrm{N}$ released after 28 days, indicating net immobilization, and $+23 \%$, indicating net mineralization, with most organic resources showing an initial $\mathrm{N}$ immobilization phase. $\mathrm{N}$ release was negatively related to the lignin-to- $\mathrm{N}$ and (lignin+polyphenol)-to-N ratios of the organic resources. Lastly, we observed that the net release of Olsen P relative to the control soil varied between 0.4 and $4.9 \mathrm{mg} \mathrm{kg}^{-1}$ and that net $\mathrm{P}$ release was positively related to the P content of the organic resources. In summary, legume age was the parameter that most strongly influenced the quality of the legume residues, and consequently its $\mathrm{N}$ and $\mathrm{P}$ release dynamics, with potentially significant consequences for $\mathrm{N}$ and $\mathrm{P}$ uptake recovery and losses and, ultimately, cropping system sustainability.
\end{abstract}

Lablab purpureus / Mucuna pruriens / N mineralization / Olsen P release / organic resource quality / Togo rock phosphate

\section{INTRODUCTION}

It is generally acknowledged by the research and development community studying declining soil fertility in SubSaharan Africa that both organic and mineral inputs are required to boost agricultural production (Vanlauwe et al., 2002). Organic resources are different from mineral inputs because plant-available nutrient release dynamics from organic resources vary widely, depending on their organic resource quality. Organic resource quality is usually expressed as a combination of $\mathrm{N}$, lignin and/or soluble polyphenol content, with high quality organic resources showing relatively quick net $\mathrm{N}$ release dynamics (Palm et al., 2001). Moreover, while availability of mineral inputs is limited largely because of socio-economic rather than technical constraints, production of a sufficient amount of organic resources is a major difficulty in areas with limited land availability, long dry seasons, and/or large livestock populations. Organic matter cut-

* Corresponding author: b.vanlauwe@cgiar.org and-carry systems involve a lot of labor, in the absence of mechanization, while in-situ production of organic resources results in competition for land with food crops. Substantial efforts have been made to evaluate the inclusion of herbaceous legumes in existing cropping systems to enhance the soil fertility status with minimal amounts of external inputs (Versteeg et al., 1998; Vanlauwe et al., 2003). From a soil fertility improvement standpoint, herbaceous legumes are usually preferred over grain legumes as most of the $\mathrm{N}$ fixed from the atmosphere by the former remains in the soil, while for the latter, a large fraction of fixed $\mathrm{N}$ is removed from the field through the harvested grains.

Organic resource quality is known to affect its decomposition and mineralization dynamics (Cadisch and Giller, 1997). A good overview of organic resource quality - N mineralization relationships was presented by Palm et al. (2001) in a paper describing the Organic Resource Database (ORD), that currently contains information on organic resource quality parameters including macronutrient, lignin and 

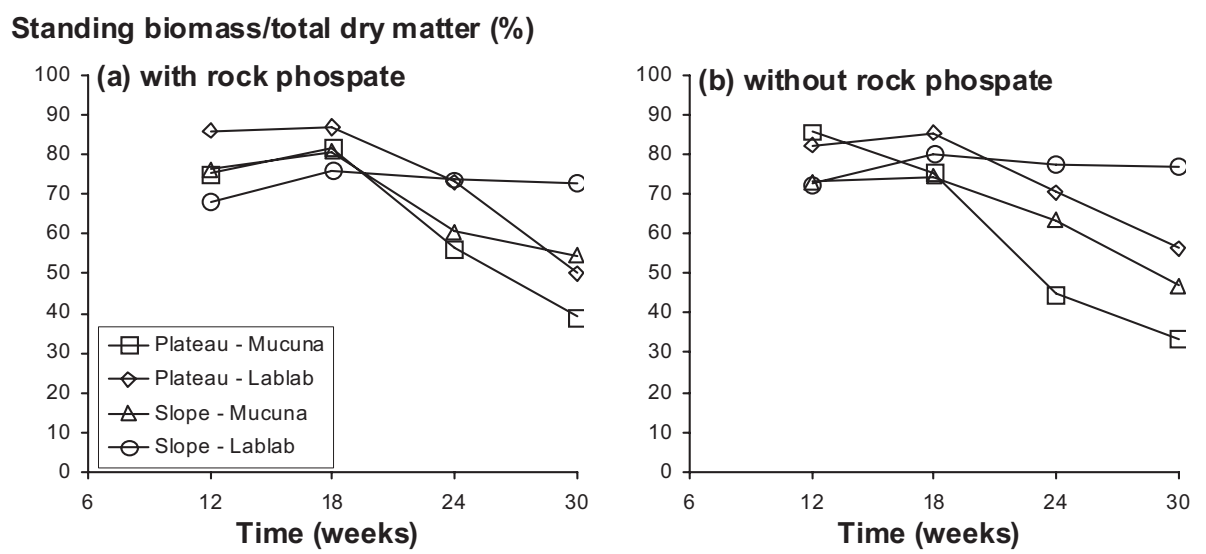

Figure 1. Ratio of standing biomass dry matter:total aboveground dry matter (standing biomass + surface litter) for the different treatments and sites, used for composing the organic resources in the incubation. 'RP' means 'rock phosphate'. Note that the ratio was determined using field assessments of dry matter production (Vanlauwe et al., 2000).

polyphenol contents of fresh leaves, litter, stems and/or roots from almost 300 species found in tropical agro-ecosystems (ftp://iserver.ciat.cgiar.org/webciat/ORD/). Organic resource quality is also not constant for one species but varies with the plant components included, plant age or physiological status, and management. Vanlauwe et al. (1997) reported that quality characteristics of tree prunings varied substantially for different canopy ages. Handayanto et al. (1995) observed that application of $\mathrm{N}$ fertilizer significantly affected $\mathrm{N}$ and polyphenol concentrations of Calliandra calothyrsus and Gliricidia sepium prunings.

Organic resources are not only a source of $\mathrm{N}$ but fulfill a number of other functions, such as enhancement of soil moisture conditions (Vanlauwe et al., 2001), improvement of the soil-available P status (Nziguheba et al., 2000), reduction in $\mathrm{Al}$ concentrations in the soil solution (Pypers et al., 2005) or amelioration of the soil organic matter pool and its quality (Cadisch and Giller, 2000) with consequent impacts on soil structure and aggregation. Nziguheba et al. (2000) observed that the $\mathrm{P}$ content of organic resources and the soluble C-tototal-P ratio were the main organic resource parameters predicting soil $\mathrm{P}$ availability and maize yield.

The objectives of this work were (i) to assess the organic resource quality of aboveground Mucuna and Lablab residues as affected by plant age, application of rock phosphate and production site, (ii) to quantify available $\mathrm{N}$ and $\mathrm{P}$ release dynamics of the above legumes as affected by the same set of factors, and (iii) to explore potential relationships between short-term $\mathrm{N}$ and $\mathrm{P}$ mineralization dynamics and organic resource quality.

\section{MATERIALS AND METHODS}

\subsection{Legume trials}

Three trials aiming at quantifying rotational effects in herbaceous legume - maize rotations as affected by application of rock phosphate to the legume were established in Kasuwan Magani, a village in the Northern Guinea savanna zone of Nigeria, along a representative toposequence. A first field, referred to as the 'plateau' field, was established on the interfluve crest on a Ferric Acrisol with a petroferric phase, a topsoil $(0-10 \mathrm{~cm})$ Olsen $\mathrm{P}$ content of $2.5 \mathrm{mg} \mathrm{kg}^{-1}$, and relatively high P sorption characteristics (Nwoke et al., 2004). A second field, referred to as the 'slope' field, was established on the more fertile valley slope between the crest and the valley bottom on a Haplic Lixisol with a petroferric phase and a topsoil $(0-10 \mathrm{~cm})$ Olsen P content of $14.1 \mathrm{mg} \mathrm{kg}^{-1}$. The petroferric layer occurred deeper in the profile $(>80 \mathrm{~cm})$ compared with the 'plateau' field. A third field, referred to as the 'valley' field, was established near the valley bottom on a Gleyic Lixisol. More details on field and site characteristics are given by Vanlauwe et al. (2000a). The trials were established in 1997 and each trial included treatments with white-seeded $\mathrm{Mu}$ cuna pruriens (L.) var utilis (Wright) Burck and white-seeded Lablab purpureus $\mathrm{L}$. with and without rock phosphate addition at a rate of $90 \mathrm{~kg} \mathrm{P} \mathrm{ha}^{-1}$. The rock phosphate was collected from the Hahotoe mine in Togo and sieved through $0.15 \mathrm{~mm}$ before application. The rock phosphate had a $\mathrm{P}$ content of $17 \%$, of which $20 \%$ was soluble in citric acid. None of the legumes was inoculated. The 'plateau' field had 3 replicates, the 'slope' field 4 replicates and the 'valley' field 4 replicates.

\subsection{Organic resource collection and quality determination}

At $6,12,18,24,30$ and 36 weeks after planting, the legume standing biomass and surface litter was sampled with a quadrant of 0.75 by $0.75 \mathrm{~m}^{2}$, placed randomly on one row, $0.5 \mathrm{~m}$ away from the end of the row (Vanlauwe et al., 2000a). The organic resources used in the current work were obtained by mixing standing biomass and surface litter material using the standing-biomass-to-surface-litter ratio as obtained for each plot and sampling date (Fig. 1). Note that older residues contained a larger proportion of surface litter, except for the Lablab residues of the 'slope' field. Only organic resources sampled between 12 and 30 weeks after planting 
on the 'plateau' and 'slope' fields from the first 3 replicates were used in this work. More details on trial management and sampling are given by Vanlauwe et al. (2000a). The legume biomass samples taken on the various sampling dates were dried $\left(65^{\circ} \mathrm{C}\right)$, weighed, ground to pass $0.5 \mathrm{~mm}$, and analyzed for total C (Amato, 1982), Kjeldhal N, total P (IITA, 1982), and lignin, using the permanganate oxidation procedure (Van Soest and Wine, 1968). The total soluble polyphenol content was quantified by Folin-Ciocalteu reagent, against a tannic acid standard after extraction of $0.1 \mathrm{~g}$ of plant material with $50 \mathrm{ml}$ of a $50 \%$ methanol-water mixture (Anderson and Ingram, 1993).

\subsection{Incubation study}

The soil used for the incubation experiment was taken from the $0-10 \mathrm{~cm}$ layer of a Ferric Lixisol from an experimental farm in Fashola, southwestern Nigeria. The soil had an organic $\mathrm{C}$ content of $9.0 \mathrm{~g} \mathrm{~kg}^{-1}$, a total $\mathrm{N}$ content of $0.72 \mathrm{~g} \mathrm{~kg}^{-1}$, a mineral $\mathrm{N}$ content of $45 \mathrm{mg} \mathrm{N} \mathrm{kg}^{-1}$ dry soil, an Olsen $\mathrm{P}$ content of $4.3 \mathrm{mg} \mathrm{kg}^{-1}$, a $\mathrm{pH} \mathrm{KCl}$ of 6.0 , an effective cation exchange capacity of $5.3 \mathrm{cmol}_{c} \mathrm{~kg}^{-1}$, a sand content of $840 \mathrm{~g} \mathrm{~kg}^{-1}$, a silt content of $100 \mathrm{~g} \mathrm{~kg}^{-1}$ and a clay content of $60 \mathrm{~g} \mathrm{~kg}^{-1}$. The soil was air-dried, sieved through $2 \mathrm{~mm}$, rewetted with distilled water to attain $40 \%$ of water-holding capacity, and kept at room temperature for 3 weeks prior to incubation. Fifty grams of pre-incubated soil were used for each incubation jar. The organic resources were ground through $1 \mathrm{~mm}$ and thoroughly mixed with the soil at a rate equivalent to $5 \mathrm{t} \mathrm{ha}^{-1}$ dry weight basis, or $0.179 \mathrm{~g}$ per $50 \mathrm{~g}$ of soil, and placed in $60 \mathrm{~mL}$ bottles. Each treatment was replicated 3 times and organic resources collected from the different field-level replicates were incubated separately. Control soils did not receive any organic resources. The bottles were placed in $1.5 \mathrm{~L}$ glass incubation jars containing $10 \mathrm{~mL}$ of distilled water to keep the soils moist during the incubation period. After 7,14 and 28 days, 3 jars per treatment were destructively sampled for mineral $\mathrm{N}$ and Olsen $\mathrm{P}$ determination. Determination of mineral $\mathrm{N}$ and Olsen $\mathrm{P}$ was also carried out at the beginning of the experiment, after the 3 weeks of pre-incubation. Ammonium $\mathrm{N}$ and nitrate $\mathrm{N}$ in the soil were determined with a scalar continuous flow analyzer after extraction of $30 \mathrm{~g}$ of soil with $90 \mathrm{~mL}$ of $2 \mathrm{~N} \mathrm{KCl}$ for 30 minutes and centrifugation at 150 revolutions per minute for 5 minutes (IITA, 1982). Olsen $\mathrm{P}$ was measured following Okalebo et al. (1993).

\subsection{Mathematical and statistical analyses}

Organic resource quality parameters were analyzed following a split-plot design (main plot: 'treatment', sub-plot: 'residue age') with the MIXED procedure of SAS (SAS, 1992), using 'treatment', 'field' and 'residue age' and their interactions as fixed effects and 'replicate within field' and 'replicate $\times$ treatment within field' as random effects. Mean separation was done with the PDIFF option of the LSMEANS statement (SAS, 1992).
The net amount of mineral $\mathrm{N}$ and Olsen $\mathrm{P}$ released was obtained by subtracting the mineral $\mathrm{N}$ or Olsen $\mathrm{P}$ content of the unamended control treatment from the treatments that received organic resources. For each sampling date, the proportional amount of residue $\mathrm{N}$ or $\mathrm{P}$ mineralized could thus be estimated as follows, with $\mathrm{N}_{\min }$ and $\mathrm{P}_{\text {Olsen }}$ referring to mineral $\mathrm{N}$ and Olsen P:

$$
\begin{aligned}
& \text { Residue } \mathrm{N} \text { mineralized }= \\
& \frac{\left(\mathrm{N}_{\text {Min }} \text { in amended soil }\right)-\left(\mathrm{N}_{\text {Min }} \text { in control soil }\right)}{\text { Residue } \mathrm{N} \text { added to amended soil }} \times 100 \%
\end{aligned}
$$

Residue $\mathrm{P}$ mineralized $=$

$$
\frac{\left(\mathrm{P}_{\text {Olsen }} \text { in amended soil }\right)-\left(\mathrm{P}_{\text {Olsen }} \text { in control soil }\right)}{\text { Residue } \mathrm{P} \text { added to amended soil }} \times 100 \%
$$

Mineral $\mathrm{N}$ is taken conventionally as the sum of ammonium $\mathrm{N}$ and nitrate N. N mineralization and Olsen $\mathrm{P}$ data were subjected to the MIXED procedure for each time of sampling separately, with 'general treatment' as fixed effect and 'incubation replicate' as random effect, and standard errors of the difference were calculated using the PDIFF option of the LSMEANS statement. 'General treatment' combines one level of 'field', 'treatment' and 'residue age'. Simple regression analysis (SAS, 1985) was used to relate $\mathrm{N}$ and $\mathrm{P}$ mineralization dynamics with various organic resource characteristics for all organic resources combined or for the Mucuna and Lablab residues separately.

\section{RESULTS AND DISCUSSION}

\subsection{Organic resource quality}

Generally, older organic resources on both fields tended to contain less $\mathrm{N}$ and $\mathrm{P}$, although differences between respective plant ages were not consistently significant (Fig. 2). Application of rock phosphate did not influence the $\mathrm{N}$ content of the Mucuna and Lablab residues on both fields but resulted in significantly higher total $\mathrm{P}$ contents of the Mucuna and Lablab aboveground biomass at 12 and 18 weeks after planting on the 'plateau' field. On the 'slope' field, rock phosphate did not affect residue $\mathrm{P}$ contents (Fig. 2). For nearly all organic resources and both fields, lignin contents did not vary significantly with residue age and rock phosphate application (Fig. 3). On the 'plateau' field, 24-week-old Mucuna residues had significantly higher polyphenol contents than the other residues, while residue age had relatively little effect on the polyphenol content of Lablab (Fig. 3). On the 'slope' field, both Mucuna and Lablab residues had higher polyphenol contents at 24 weeks. In most cases, application of rock phosphate did not influence the polyphenol content of both legumes on both sites (Fig. 3).

First, the above data clearly show that for both species, organic residue age had a major impact on its $\mathrm{N}, \mathrm{P}$ and polyphenol contents, and a minor impact on its lignin content. 
Total $\mathrm{N}$ content ( $\%$ dry matter)
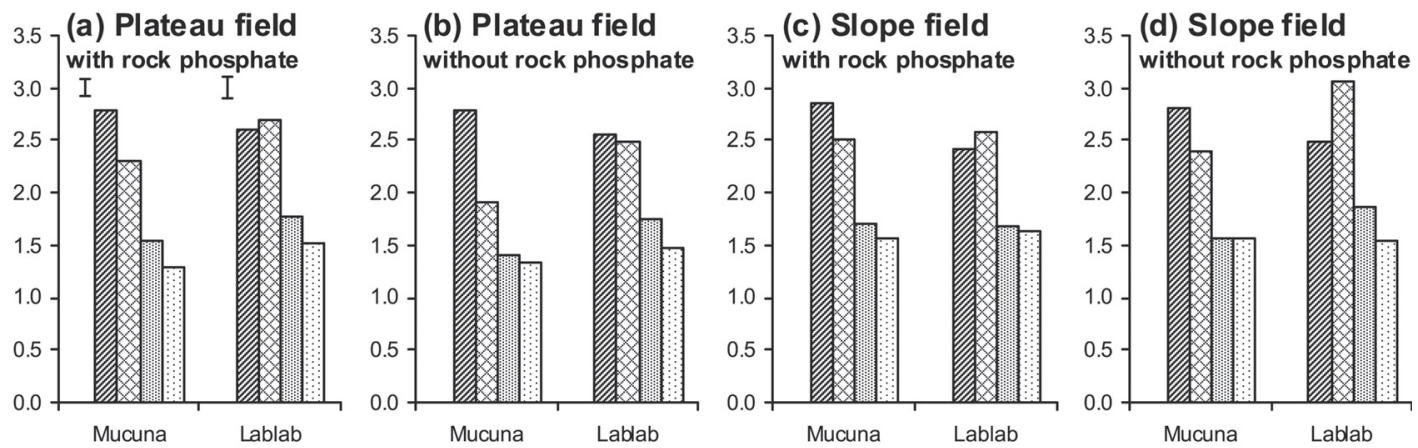

Total P content (\% dry matter)
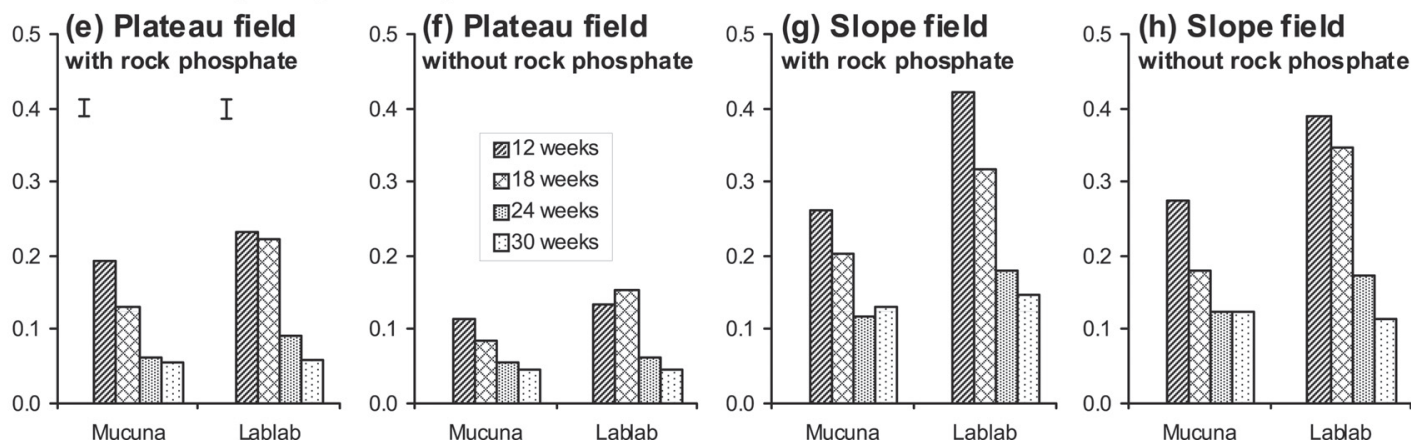

Figure 2. Total $\mathrm{N}$ content of the organic resources produced on the 'plateau' (a), (b) and 'slope' (c), (d) fields and total P content of these resources produced on the 'plateau' (e), (f) and 'slope' (g), (h) fields. The left error bars indicate the Standard Errors of the Difference (SED) between sampling times for one treatment, the right error bars indicate the SED between treatments at one sampling time. 'RP' means 'rock phosphate'.

At 24 weeks, both legume $\mathrm{N}$ and $\mathrm{P}$ contents fell to about half their values at 12 weeks of age. Decline in nutrient contents of legumes with age is a well-known phenomenon and caused by advancing cell-wall formation, a decreasing leaf-to-stem ratio (Lloveras and Iglesias, 2001), an increasing proportion of senescent plant parts, and translocation of $\mathrm{N}$ and $\mathrm{P}$ from the leaves and stems to the inflorescences with increasing plant age (Ozanne, 1986). In Tanzania, Mero and Uden (1997) observed decreases in crude protein and in-vitro digestibility for various grasses and legumes between 4 and 10 weeks of age. Gunther et al. (1988) similarly observed decreasing crude protein and $\mathrm{P}$ contents with increasing ages of pasture fodders in Tanzania. Differences in the above parameters between 24 and 30 weeks are minimal as this period fell within the dry season (Vanlauwe et al., 2000a).

Secondly, the above data also show that total soluble polyphenol contents varied considerably between fields and organic resource ages for the same species. Tannins in plant materials are commonly associated with defenses against herbivore activity and plant materials containing over $2 \%$ tannins are usually less attractive for feeding because of their astringency (Swain, 1979). Tannins can also protect plants against fungal and bacterial attachment by encapsulating plant molecules and inhibiting essential enzymes of attaching organisms (Swain, 1979). The lower polyphenol content of younger leaves, observed in the current trials, does not agree with earlier observations by Mafongoya et al.
(1997), who reported higher soluble polyphenol contents of younger tree prunings and attributed this to the need for better protection against herbivore activity for younger prunings with a higher soluble cell content, e.g., proteins and sugars. The higher polyphenol contents of the 24-week-old Mucuna residues is also not caused by the higher proportion of surface litter at that time, as analysis of the Organic Resource Database (ftp://iserver.ciat.cgiar.org/webciat/ORD/) shows that for 5 genera (Dolichos spp., Stylosanthes spp., Centrosema spp., Calliandra spp. and Leucaena spp.), surface litter contains between 1.0 and 0.5 times the amount of soluble polyphenols of fresh leaves. The most likely reason for this increase is the increased formation of polyphenols as the plants are entering the dry season with likely increases in potential attacks by insects. The relative composition of polyphenols can also change as a function of changes in environmental conditions (Harborne, 1997), which may explain differences in polyphenol contents between the two sites for the same species, although it is not possible to identify specific changes in such conditions.

Lastly, application of rock phosphate only appeared to have had a major influence on the P content of both legumes on the 'plateau' field, although their P contents in the presence of rock phosphate $(0.20-0.23 \%)$ were still far below the $\mathrm{P}$ contents of the legumes observed on the 'slope' field $(0.26-0.40 \%)$, which was previously observed to contain sufficient amounts of available $\mathrm{P}$ to preempt any responses to 


\section{Lignin content (\% dry matter)}
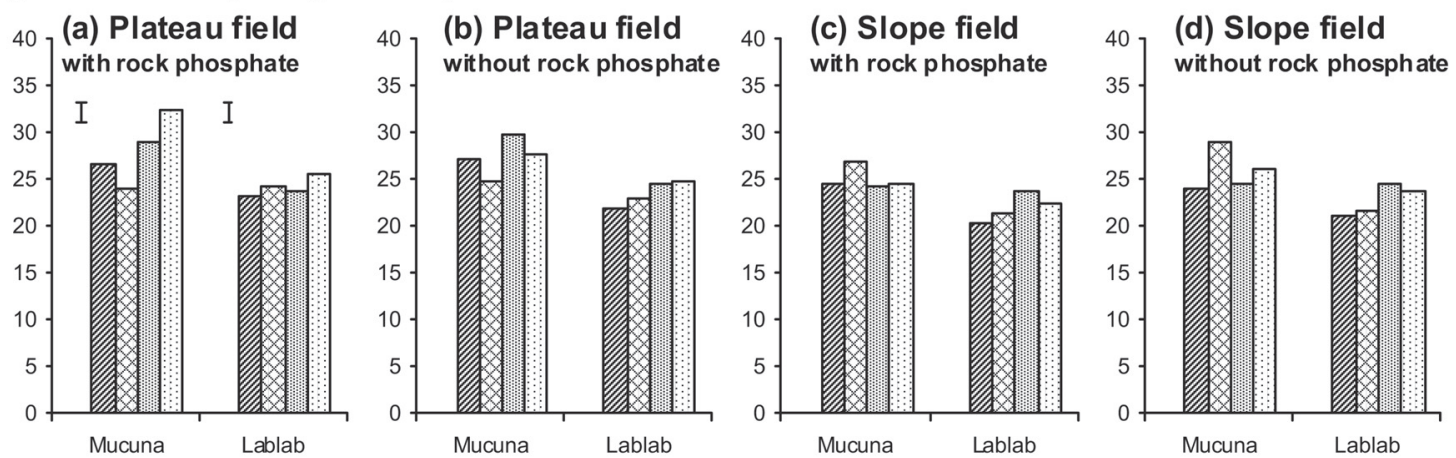

\section{Polyphenol content (\% dry matter)}
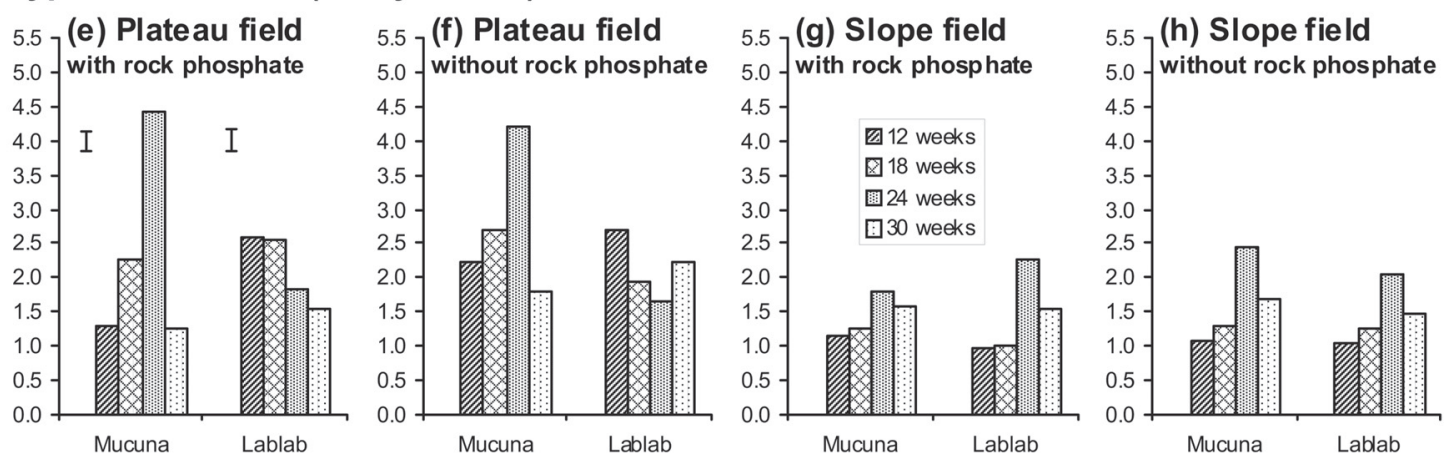

Figure 3. Lignin content of the organic resources produced on the 'plateau' (a), (b) and 'slope' (c), (d) fields and polyphenol content of these resources produced on the 'plateau' (e), (f) and 'slope' (g), (h) fields. The left error bars indicate the Standard Errors of the Difference (SED) between sampling times for one treatment, the right error bars indicate the SED between treatments at one sampling time. 'RP' means 'rock phosphate'.

\section{Proportion of $\mathrm{N}$ released (\%)}
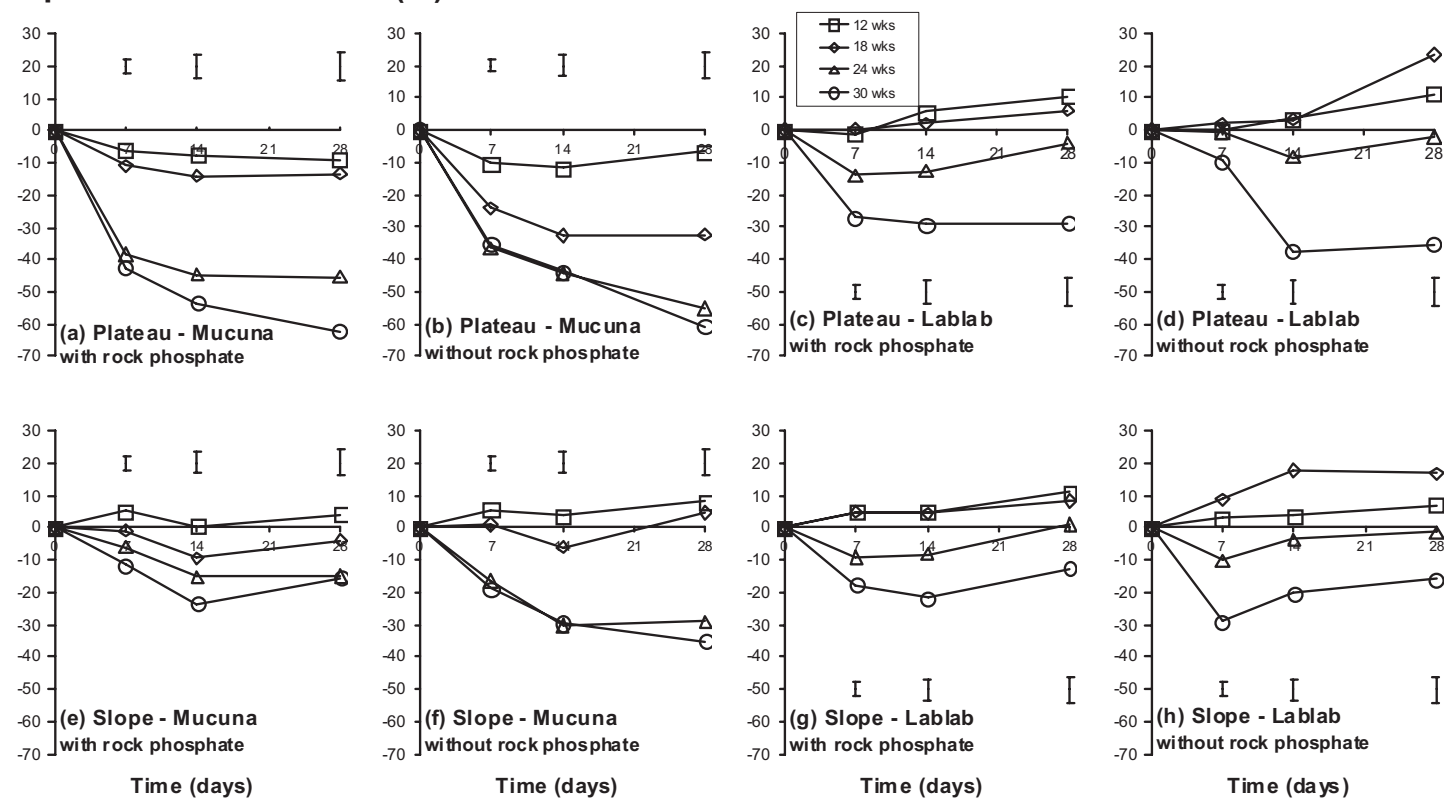

Figure 4. Proportional release of applied organic resource N during the incubation for the Mucuna (a), (b) and Lablab (c), (d) residues on the 'plateau' field and for the Mucuna (e), (f) and Lablab (g), (h) residues on the 'slope' field, as affected by residue age ('wks' means weeks after planting) and application of rock phosphate ('RP' means rock phosphate). Error bars are Standard Errors of the Difference, calculated for each sampling time. 

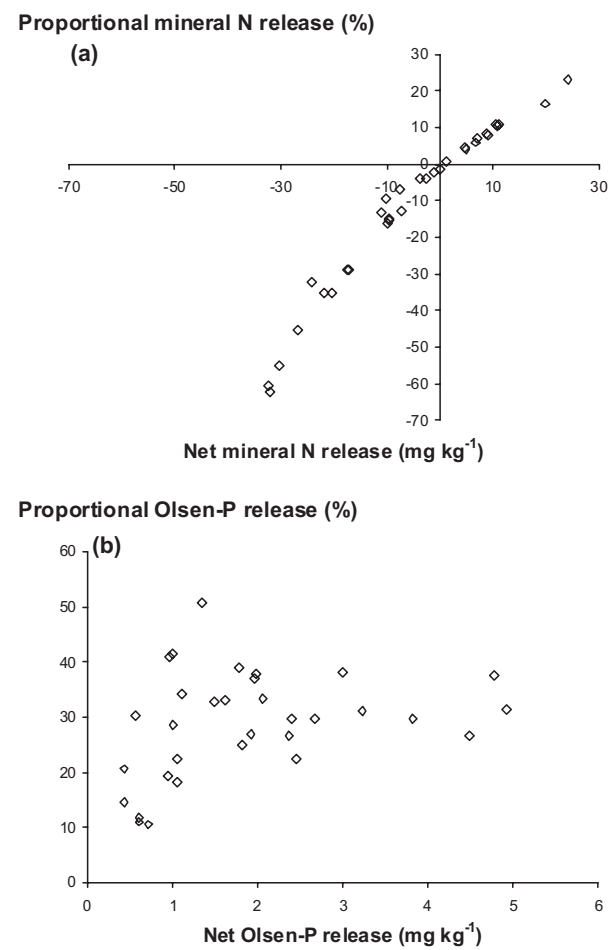

Figure 5. Relationship between proportional and net mineral $\mathrm{N}$ release, (a) and between proportional and net Olsen $\mathrm{P}$ release (b) for all organic resources used in the incubation study. The proportional release of $\mathrm{N}$ or $\mathrm{P}$ was calculated using Equations (1) and (2), while the net release of $\mathrm{N}$ and $\mathrm{P}$ was obtained by subtracting the mineral $\mathrm{N}$ or Olsen $\mathrm{P}$ content of the unamended control treatment from the treatments that received organic resources. Negative values in (a) indicate $\mathrm{N}$ immobilization where the mineral $\mathrm{N}$ contents in treated soils are less than those in the control soils.

application of rock phosphate (Vanlauwe et al., 2000a). In the latter site, $\mathrm{P}$ appears to have been accumulated at concentrations above those required for optimal legume growth, while at the former site, $\mathrm{P}$ appeared to have been the major limiting nutrient for legume biomass accumulation, especially in the absence of rock phosphate additions.

In summary, the presented organic resource quality-related observations clearly show that organic resource age had an impact on its quality, mainly in terms of N, P and polyphenol contents. Application of rock phosphate only altered the $\mathrm{P}$ content of the legumes on the site that had a relatively low available soil P content. Since organic resource quality has been shown to be related to its mineralization and decomposition dynamics, these management factors are likely going to affect the nutrient cycling behavior of these organic resources with potentially significant consequences for $\mathrm{N}$ and $\mathrm{P}$ crop recovery and losses, as discussed in the next section.

\subsection{Mineral $\mathbf{N}$ dynamics and relationships with organic resource quality}

Residue age significantly affected $\mathrm{N}$ mineralization dynamics of residues grown both with and without rock phosphate addition (Fig. 4). Generally, younger residues led to a higher $\mathrm{N}$ mineralization than older residues, although the differences between each age class were not always significant. Application of rock phosphate did not affect the $\mathrm{N}$ mineralization dynamics of most organic resources derived from both fields. The only residues showing higher $\mathrm{N}$ mineralization values for all incubation periods when grown with rock phosphate addition were the 18-week Mucuna residues from the 'plateau' field (Fig. 4). Net $\mathrm{N}$ release values were highly correlated with proportional residue $\mathrm{N}$ release dynamics (Fig. 5a), as the amount of residue $\mathrm{N}$ applied varied narrowly between $102 \pm 14 \mathrm{mg} \mathrm{N} \mathrm{kg}^{-1}$ for organic resources with net $\mathrm{N}$ mineralization after 28 days and between $72 \pm 18 \mathrm{mg} \mathrm{N} \mathrm{kg}^{-1}$ for organic resources with net $\mathrm{N}$ immobilization after 28 days. These different $\mathrm{N}$ addition rates for organic resources mineralizing and immobilizing $\mathrm{N}$ also explain the steeper slope for immobilizing resources in Figure 5a. When considering all residues used $(n=32)$, net $\mathrm{N}$ release and proportional $\mathrm{N}$ mineralization after 28 days were significantly and linearly related to the following organic resource quality characteristics: $\mathrm{N}$ content, $\mathrm{P}$ content, lignin content, $\mathrm{C}-$ to- $\mathrm{N}$ ratio, lignin-to$\mathrm{N}$ ratio, polyphenol-to- $\mathrm{N}$ ratio, (lignin + polyphenol)-to-N ratio, C-to-P ratio, lignin-to-P ratio, polyphenol-to-P ratio and (lignin + polyphenol)-to-P ratio (Tab. I, Fig. 6a).

The above data show that the organic resources used in this experiment belonged to classes II and IV as proposed by Palm et al. (2001) in the Decision Support System for organic N management. Class II resources have a $\mathrm{N}$ content above $2.5 \%$ and either $>4 \%$ soluble polyphenols or $>15 \%$ lignin and are advised to be applied in combination with $\mathrm{N}$ fertilizer or high quality organic resources of Class I. This addition of available $\mathrm{N}$ is meant to overcome potential $\mathrm{N}$ immobilization. Class IV resources have a $\mathrm{N}$ content $<2.5 \%$ and a lignin content $>15 \%$ and are advised to be applied as surface mulch as their decomposition is likely going to be slow (Palm et al., 2001). Herbaceous legume biomass is often associated with class I or high quality organic resources $(>2.5 \% \mathrm{~N},<4 \%$ soluble polyphenols, $<15 \%$ lignin), with fast $\mathrm{N}$ release dynamics and substantial residual effects on a following cereal, but in the current study, legume materials were shifting between classes as their age increased, with obvious impacts on their $\mathrm{N}$ release characteristics. While all organic resources of 30 weeks old immobilized $\mathrm{N}$ during this 28 day incubation, this immobilization period must have been overcome under field conditions as the responses of rock phosphate addition to enhanced legume biomass production was clearly reflected in crop and stover yields of the subsequent maize crop (Vanlauwe et al., 2000b). Nitrogen and lignin were observed to be the organic resource characteristics having the highest impact on $\mathrm{N}$ mineralization dynamics, as previously observed and explained by other authors (Melillo et al., 1982; Vanlauwe et al., 1996).

Furthermore, contrary to other reports presenting data on $\mathrm{N}$ mineralization dynamics of leguminous materials (Palm and Sanchez, 1991; Oglesby and Fownes, 1992), the apparent limited influence of soluble polyphenols on the $\mathrm{N}$ mineralization dynamics in the current work may be explained by the high proportion of surface litter in the organic resources used, with 
Table I. R-square values of the simple linear regressions between selected $\mathrm{N}$ mineralization and Olsen $\mathrm{P}$ dynamics at 28 days and commonly used organic resource characteristics for average values of all residues $(n=32)$.

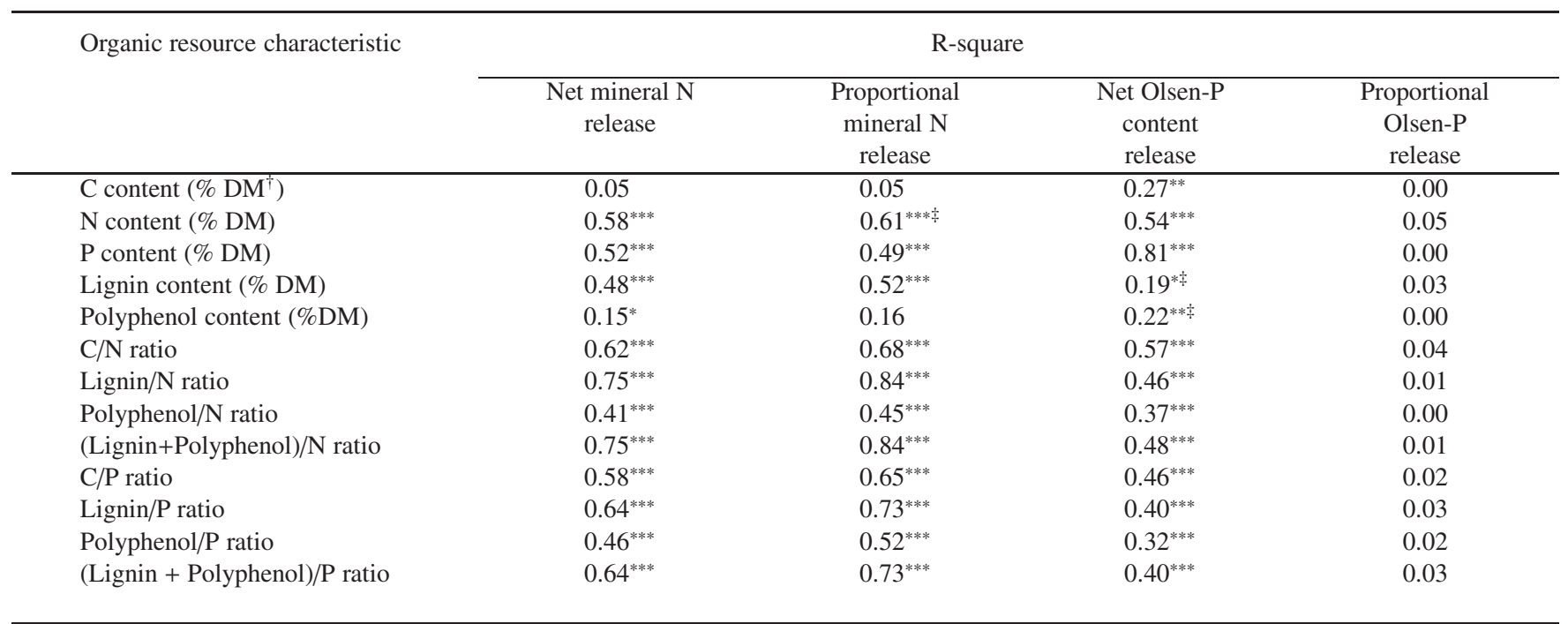

$\dagger \mathrm{DM}=$ dry matter.

$\$ *, * *$ and ${ }^{* * *}$ indicate significance at the 5,1 and $0.1 \%$ levels, respectively.

Proportion of added $\mathrm{N}$ mineralized at day $28(\%)$

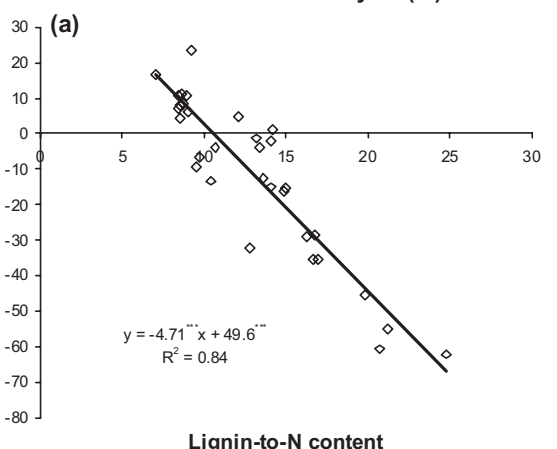

Net Olsen-P content at day $28(\mathrm{mg} \mathrm{kg}-1)$

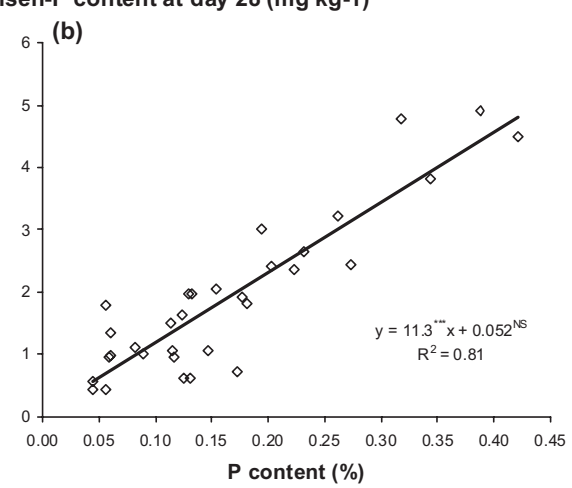

Figure 6. Relationship between the proportion of the added residue $\mathrm{N}$ mineralized after 28 days and the lignin-to-N content of the organic resources (a), and between the net amount of Olsen $\mathrm{P}$ in the soils treated with organic resources and the $\mathrm{P}$ content of these resources (b). All organic resources are included in the regression analysis. Negative values in (a) indicate $\mathrm{N}$ immobilization where the mineral $\mathrm{N}$ contents in treated soils are less than those in the control soils. potential decreases in amounts of soluble polyphenols upon drying of the plant materials (Mafongoya et al., 1997).

In summary, although the $\mathrm{N}$ mineralization dynamics of the organic resources used followed previously reported trends, except for the lack of substantial polyphenol - $\mathrm{N}$ interactions, the organic resources were observed to shift between organic resource classes, as defined by Palm et al. (2001), with potential consequences for their $\mathrm{N}$ release dynamics and supply to a growing crop.

\subsection{Olsen $\mathbf{P}$ dynamics and relationships with organic resource quality}

When grown in the presence of rock phosphate, younger residues tended to result in higher net changes in Olsen P contents in the receiving soil compared with older residues, although differences between residue ages were not always significant (Fig. 7). When grown in the absence of RP, the age effect of Mucuna and Lablab from the 'plateau' field was not significant in most instances. For the residues produced on the 'slope' field, younger residues released consistently more Olsen P than older residues, although, as above, differences were not always significant (Figs. 7e-h). Proportional Olsen P values were not correlated with net Olsen $P$ values and varied between $11 \%$ and $51 \%$ (Fig. 5b). Of the 32 organic resources used, 25 showed proportional Olsen $\mathrm{P}$ release within a narrow range, $32 \% \pm 6 \%$. The best $\left(\mathrm{R}^{2}=0.81\right)$ relationship between net Olsen P release and organic resource quality was obtained with the P content of the organic resources (Tab. I; Fig. 6b). Proportional amounts of $\mathrm{P}$ release as measured by the net increases in Olsen $P$ of the receiving soil were not significantly related to any of the other organic resource quality parameters (Tab. I). 


\section{Olsen-P content $\left(\mathrm{mg} \mathrm{kg}^{-1}\right)$}
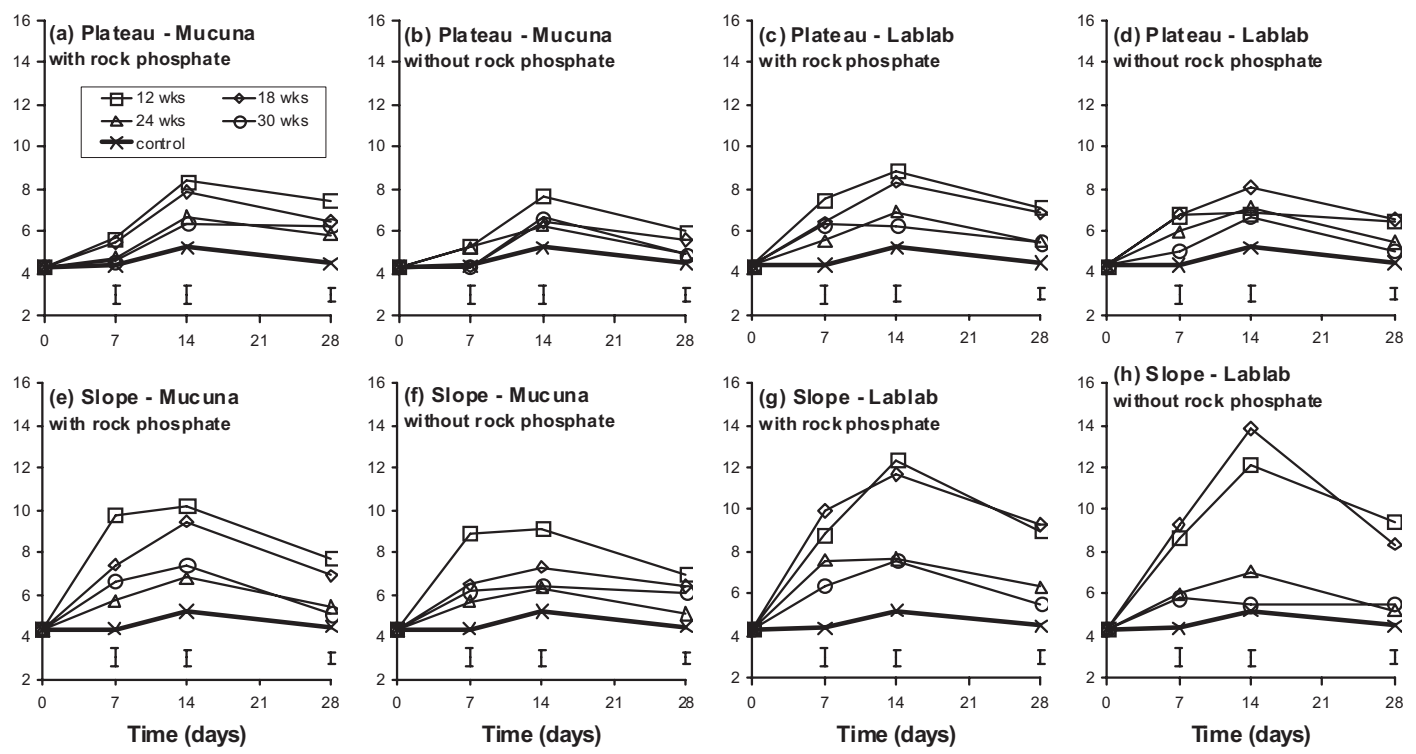

Figure 7. Olsen P content during the incubation for the treatments with Mucuna (a), (b) and Lablab (c), (d) residues, obtained from the 'plateau' field and for the treatments with Mucuna (e), (f) and Lablab (g), (h) residues, obtained on the 'slope' field, as affected by residue age ('wks' means weeks after planting) and application of rock phosphate ('RP' means rock phosphate). Olsen-P contents of the control soil are also included. Error bars are Standard Errors of the Difference, calculated for each sampling time.

The above data indicated that, contrary to $\mathrm{N}$, the organic resources contained sufficient $P$ to allow microbial degradation to proceed, resulting in net $\mathrm{P}$ mineralization, since Olsen $\mathrm{P}$ contents in all treatments were higher than or equal to Olsen $\mathrm{P}$ contents of the control soil at all incubation times. Palm et al. (1997) stated that organic materials with $<0.25 \% \mathrm{P}$ will immobilize P. Pypers et al. (2005) observed increases in available $\mathrm{P}$, as measured by a resin method, upon addition of $\mathrm{P}$-rich residues. All residues used in their study had C-to-P ratios below 200, and increases in available $\mathrm{P}$ were well predicted by their $\mathrm{P}$ content, large concentrations of soluble $\mathrm{P}$ and narrow C-to-P or C-to-soluble-P ratios. Nziguheba et al. (2000) indicated a threshold for the soluble-C-to-P ratio of the residue of 30. Under this threshold, immobilization would become likely. In this study, over half of the organic resources have either a $\mathrm{P}$ content below $0.25 \%$ or a C-to-P ratio exceeding 200. C-to-P ratios are $181 \pm 91$ for 12 -week-old residues, $239 \pm 129$ for 18 -week-old residues, $461 \pm 216$ for 24 -week-old residues and $541 \pm 265$ for 30 -week-old residues. Increases in Olsen P contents after addition of organic resources with $\mathrm{C}$-to-P ratios of 77, 227 and 704 were also observed by Umrit and Friesen (1994). The lack of P immobilization for organic resources with $<0.25 \% \mathrm{P}$ and/or C-to-P ratios exceeding 200 could be explained by the different proportions of inorganic and organically bound $\mathrm{P}$ in plant materials with consequent influences on P release dynamics (Umrit and Friesen, 1994). The Olsen extractant could also have extracted part of the microbiallyimmobilized $P$.

Furthermore, organic resource quality did not appear to interfere with Olsen $\mathrm{P}$ release dynamics, as high correlations were observed between $\mathrm{P}$ content and net Olsen $\mathrm{P}$ release. This indicates that more $\mathrm{P}$ added to the organic resources re- sulted in more net Olsen $\mathrm{P}$ release. The narrow range of proportional Olsen $P$ release values for organic resources with net Olsen P release over $1 \mathrm{mg} \mathrm{kg}^{-1}$ and the consequent lack of relationships between proportional Olsen P release and organic resource characteristics further supports this. Calculations of proportional $\mathrm{P}$ release for treatments with less than $1 \mathrm{mg} \mathrm{kg}^{-1}$ net Olsen $\mathrm{P}$ release were likely not very accurate

In summary, all organic resources used increased the soil Olsen P content, indicating net release of P from all these resources. The net increases in Olsen $\mathrm{P}$ were closely related to the $\mathrm{P}$ content of the organic resources used, indicating that other organic resource quality characteristics did not interfere with P mineralization dynamics.

\section{CONCLUSION}

The quality of the herbaceous legume organic resources used and their $\mathrm{N}$ and $\mathrm{P}$ mineralization dynamics depended on their age or physiological status, whereby best immediate responses to herbaceous legume addition are expected from younger materials. Application of rock phosphate only enhanced the $\mathrm{P}$ content of the legume residues on the site with low available soil P. Since the time of application or incorporation of the legume residues is likely going to affect the supply of $\mathrm{N}$ and $\mathrm{P}$, for agro-ecosystem sustainability, it will be essential to match this supply with crop demand for these nutrients. Manipulating legume age, however, is often severely restricted as the legume inputs are required at the time of planting of the cereal crop. The range of options available to manipulate legume biomass and quality is likely less as the length of the dry season increases and as the rainy season changes from 
bimodal to unimodal. In areas with a single cropping season per year, for example, legume residues necessarily mature and remain on the soil surface during the dry season, with often marginal amounts of organic matter remaining at planting.

Acknowledgements: The authors are grateful to the DGDC, the Belgian Directorate General for Development Cooperation, for sponsoring this work as part of the collaborative project between the KU Leuven and the IITA on 'Balanced Nutrient Management Systems for Maize-based Farming Systems in the Moist Savanna and Humid Forest Zone of West-Africa'. Mr. S. Bako is acknowledged for his day-to-day supervision of the trials.

\section{REFERENCES}

Amato M. (1982) Determination of carbon ${ }^{12} \mathrm{C}$ and ${ }^{14} \mathrm{C}$ in plant and soil, Soil Biol. Biochem. 15, 611-612.

Anderson J.M., Ingram J.S.I. (1993) Tropical Soil Biology and Fertility: A Handbook of Methods, CAB International, Wallingford, UK.

Cadisch G., Giller K.E. (1997) Driven by Nature. Plant Litter Quality and Decomposition, CAB International, Oxon, UK.

Cadisch G., Giller K.E. (2000) Soil organic matter management: The role of residue quality in carbon sequestration and nitrogen supply, in: Rees R.M., Ball B., Watson C., Campbell C. (Eds.), Sustainable Management of Soil Organic Matter, CAB International, Wallingford, UK, pp. 97-111.

Gunther K.D., Mohme H., Rukantabula A. (1988) The mineral content of pasture fodders at Mpwapwa, Tanzania, and the influence of Ca$\mathrm{P}$ supplementation and different starch and urea levels in the diet on some metabolic parameters in sheep, Giessener Beitrage zur Entwicklungsforschung Symposien 17, 255-266.

Handayanto E., Cadisch G., Giller K.E. (1995) Manipulation of quality and mineralization of tropical legume tree prunings by varying nitrogen supply, Plant Soil 176, 149-160.

Harborne J.B. (1997) Role of phenolic secondary metabolites in plants and their degradation in nature, in: Cadisch G., Giller K.E. (Eds.), Driven by Nature. Plant Litter Quality and Decomposition, CAB International, Oxon, UK, pp. 67-74.

International Institute of Tropical Agriculture (1982) Automated and semi-automated methods for soil and plant analysis, Manual series No. 7, IITA, Ibadan, Nigeria.

Lloveras J., Iglesias I. (2001) Morphological development and forage quality changes in crimson clover (Trifolium incarnatum L.), Grass Forage Sci. 56, 395-404.

Mafongoya P.L., Dzowela B.H., Nair P.K. (1997) Effect of multipurpose trees, age of cutting and drying method on pruning quality, in: Cadisch G., Giller K.E. (Eds.), Driven by Nature. Plant Litter Quality and Decomposition, CAB International, Oxon, UK, pp. 167-174.

Mero R.N., Uden P. (1997) Promising tropical grasses and legumes as feed resources in central Tanzania. I. Effect of different cutting patterns on production and nutritive value of six grasses and six legumes, Trop. Grasslands 31, 549-555.

Melillo J.M., Aber J.D., Muratore J.F. (1982) Nitrogen and lignin control of hardwood leaf litter decomposition dynamics, Ecology 63, 621626.

Nwoke O.C., Vanlauwe B., Diels J., Sanginga N., Osonubi O. (2004) The distribution of phosphorus fractions and desorption characteristics of some soils in the moist savanna zone of West Africa, Nutr. Cycl. Agroecosys. 69, 127-141.

Nziguheba G., Merckx R., Palm C.A., Rao M.R. (2000) Organic residues affect phosphorus availability and maize yields in a Nitisol of western Kenya, Biol. Fert. Soils 32, 328-339.

Oglesby K.A., Fownes J.H. (1992) Effects of chemical composition on nitrogen mineralization from green manures of seven tropical leguminous trees, Plant Soil 143, 127-132.

Okalebo J.R., Gathua K.W., Woomer P.L. (1993) Laboratory Methods of Soil and Plant Analysis: A working Manual, Tropical Soil Biology and Fertility Programme, Nairobi, Kenya.
Ozanne P.G. (1986) Phospate nutrition of plants - a general treatise, in: Khasawneh F.E., Sample E.C., Kamprath E.J. (Eds.), The Role of Phosphorus in Agriculture, American Society of Agronomy, Madison, USA, pp. 559-589.

Palm C.A., Sanchez P.A. (1991) Nitrogen release from the leaves of some tropical legumes as affected by their lignin and polyphenolic contents, Soil Biol. Biochem. 23, 83-88.

Palm C.A., Myers R.J.K., Nandwa S.M. (1997) Combined use of organic and inorganic nutrient sources for soil fertility maintenance and replenishment, in: Buresh R.J., Sanchez P.A., Calhoun F. (Eds.), Replenishing Soil Fertility in Africa, Soil Science Society of America Special Publication Number 51, Madison, Wisconsin, USA, pp. 193-217.

Palm C.A., Gachengo C.N., Delve R.J., Cadisch G., Giller K.E. (2001) Organic inputs for soil fertility management in tropical agroecosystems: application of an organic resource database, Agr. Ecosyst. Environ. 83, 27-42.

Pypers P., Verstraete S., Cong P.T., Merckx R. (2005) Changes in mineral nitrogen, phosphorus availability and salt-extractable aluminium following the application of green manure residues in two weathered soils of South Vietnam, Soil Biol. Biochem. 37, 163-172.

SAS (1985) SAS User's Guide: Statistics, 5 ed., SAS Institute Inc. Cary, NC, USA.

SAS (1992) The MIXED procedure. SAS Technical Report P-229: SAS/STAT Software: Changes and Enhancements, SAS Institute Inc., Cary, NC, USA, pp. 287-366.

Swain T. (1979) Tannins and lignins, in: Rosenthal G.A., Janzen D.H. (Eds.), Herbivores Their Interactions with Secondary Plant Metabolites, Academic Press, New York, USA, pp. 657-682.

Umrit G., Friesen D.K. (1994) The effect of C:P ratio of plant residues added to soils of contrasting phosphate sorption capacities on P uptake by Panicum maximum (Jacq.), Plant Soil 158, 275-285.

Vanlauwe B., Nwoke O.C., Sanginga N., Merckx R. (1996) Impact of residue quality on the $\mathrm{C}$ and $\mathrm{N}$ mineralization of leaf and root residues of three agroforestry species, Plant Soil 183, 221-231.

Vanlauwe B., Sanginga N., Merckx R. (1997) Decomposition of four leucaena and senna prunings in alley cropping systems under subhumid tropical conditions: The process and its modifiers, Soil Biol. Biochem. 29, 131-137.

Vanlauwe B., Nwoke O.C., Diels J., Sanginga N., Carsky R.J., Deckers J., Merckx R. (2000a) Utilization of rock phosphate by crops on a representative toposequence in the Northern Guinea savanna zone of Nigeria: Response by Mucuna pruriens, Lablab purpureus, and maize, Soil Biol. Biochem. 32, 2063-2077.

Vanlauwe B., Diels J., Sanginga N., Carsky R.J., Deckers J., Merckx R. (2000b) Utilization of rock phosphate by crops on a representative toposequence in the Northern Guinea savanna zone of Nigeria: Response by maize to previous herbaceous legume cropping and rock phospate treatments, Soil Biol. Biochem. 32, 2079-2090.

Vanlauwe B., Aihou K., Aman S., Iwuafor E.N.O., Tossah B.K., Diels J., Sanginga N., Merckx R., Deckers S. (2001) Maize yield as affected by organic inputs and urea in the West-African moist savanna, Agron. J. 93, 1191-1199.

Vanlauwe B., Diels J., Sanginga N., Merckx R. (2002) Integrated plant nutrient management in sub-Saharan Africa: From Concept to Practice, CABI, Wallingford, UK.

Vanlauwe B., Bationo A., Carsky R.J., Diels J., Sanginga N., Schulz S. (2003) Enhancing the contribution of legumes and biological nitrogen fixation in cropping systems: experiences from West Africa, in: Waddington S.R. (Ed.), Grain Legumes and Green Manures for Soil Fertility in Southern Africa: Taking Stock of Progress, Soil Fertility and Policy Network for Maize-based Cropping Systems in Southern Africa, Harare, Zimbabwe, pp. 3-13.

Van Soest P.J., Wine R.H. (1968) Determination of lignin and cellulose in acid-detergent fiber with permanganate, J. Assoc. Off. Agr. Chem. $51,780-785$.

Versteeg M.N., Amadji F., Eteka A., Gogan A., Koudokpon V. (1998) Farmers' adoptability of Mucuna fallowing and agroforestry technologies in the coastal savanna of Benin, Agr. Syst. 56, 269-287. 